\title{
THE DUALIST PROJECT AND THE REMOTE-CONTROL OBJECTION
}

\section{SUBSTANCE DUALISM}

Substance dualism—'dualism' for short—-makes three claims. First, there are thinking things: beings with mental properties. (I'll follow Descartes in using the word 'thinking' to include any mental state or activity: belief, sensation, emotion, memory, and so on.) Second, there are material things: beings made entirely of matter - that is, of the atoms we learn about in science class. Third, no thinking thing is a material thing. What appears to be a material thinker like a human being or a dog is really two things: a material but unthinking thing or "body" and an immaterial thinking thing or "soul."

$M y$ soul is the immaterial thing that thinks my thoughts. And $m y$ body is the material thing that I interact with in a special way. I can move it at will, just by intending to move. And I can't move anything without moving it: I can move my desk only by moving my body. Further, I can perceive physical objects and events only by means of its sense organs. So my body is, as Richard Swinburne says, "the vehicle of my agency in the world and my knowledge of the world." Or maybe it's the largest such vehicle. I can move my left foot at will, and I can perceive physical objects and events by means of it, yet no one would say that my foot was my body. (My body isn't ten inches long.) It's only a part of my body, by being a part of a larger vehicle of my agency and sense perception.

ERIC T. Olson, Professor of Philosophy; address for correspondence: 13 Wath Road, Sheffield S7 1HD, UK; e-mail: olson.et1066@gmail.com; ORCID: https://orcid.org/0000-0002-2199-2083.

${ }^{1}$ Richard Swinburne, "Personal Identity: The Dualist Theory," in Personal Identity, ed. Sydney Shoemaker and Richard Swinburne (Oxford: Blackwell, 1984), 22; see also SwINBURne, The Evolution of the Soul, rev. ed. (Oxford: OUP, 1997), 146. 
So dualism says that thinking things are immaterial souls. Given that we think, it would seem to follow that we ourselves are souls. But some say instead that each of us is composed of both a soul and a body: my soul and my body are parts of me, and every part of me shares a part with at least one of them. I am conscious in the derivative sense of having a conscious part and visible in the derivative sense of having a visible part, but no part of me is both conscious and visible. This is Swinburne's view. ${ }^{2}$ So his answer to the question forming the title of his latest book, Are We Bodies or Souls? is that we're neither.

\section{THE REMOTE-CONTROL OBJECTION}

Here is an objection to dualism in either form. We know that small changes in the brain - a sharp blow to the head or general anaesthesia, for instance - can stop all mental activity. That's what we should expect if mental activity takes place in the brain: a mechanical or chemical change in the brain affects its activities, and those of its activities that are mental may thereby come to a stop. But what if mental activity takes place in the soul? It has no parts to be displaced or chemistry to be altered. No physical event can damage it. How could a change in the brain stop the soul's activity?

What a change in the brain could affect is its communication with the soul. According to dualism, one of the brain's functions is to enable the soul to interact with the physical world. It's the interface between the physical realm and the nonphysical one. The information from your sense organs is passed to the brain, processed, and then transmitted to the soul, where it causes sensations. And when you walk, a mental act in the soul sends information to the brain, which converts it into signals that cause muscles to contract and relax in a way that produces the intended movement. (This is the causal interaction that "matches up" souls and bodies.) A change in the brain could prevent it from sending information to the soul, depriving you of sense-perception. And it could prevent the brain from receiving information from the soul, leaving you paralyzed. This would cut your lines of communication with the physical world.

Because the soul shares no parts with the brain, however, we should expect those of its activities that don't involve sense perception to continue unhindered. And if your mental activity takes place entirely in the soul, you ought to remain fully conscious.

${ }^{2}$ SwInBuRne, The Evolution of the Soul, 145; Swinburne, Are We Bodies or Souls? (Oxford: OUP, 2019), 1; see also Eric T. Olson, "A Compound of Two Substances," in Soul, Body, and Survival, ed. Kevin Corcoran (Ithaca, NY: Cornell University Press, 2001). 
But that's not what happens. General anaesthesia causes complete unconsciousness. There can be no mental activity unless your brain is working properly. If mental activity took place in the soul, this would be baffling. Communication with the body may be necessary for the soul to act in and perceive the physical world, but not for it to think at all.

Likewise, dualism would lead us to expect the consumption of intoxicants to interfere with the brain's functioning, hampering bodily movements and perhaps distorting the sensory information it passes to the soul. But mental activity not involving bodily movements or sense perception should continue unhindered, so that we remain clear-headed.

Dualism suggests that the relation between the body and the soul is like that between a remote-control vehicle with a camera and its human operator. ${ }^{3}$ The soul affects the body's movements much as you might affect the movements of a drone. And the soul perceives the physical world by means of the body's sense organs much as you might "see" by means of the drone's camera. Disruption of the brain's mechanisms is like damage to those parts of the drone that pass signals to and from its operator. But while this may prevent the operator from controlling the drone and perceiving by means of its camera, it could not prevent her from remaining conscious. (The analogy is not perfect. When your body is injured, your senses don't simply inform you of this fact as the drone's camera informs you of things. It hurts. That's why Descartes says: "I am not merely present in my body like a sailor is present in a ship. ${ }^{\prime 4}$ But that doesn't alter the current point.)

We should expect the functioning of the body and the soul to be as independent as the functioning of a drone and its operator, contrary to our experience with general anaesthetics and head injuries. Imagine a human being who could not remain conscious even for a moment unless the drone she controls is intact. That would be mysterious. Dualism is mysterious in the same way.

\section{ELECTRIC DUALISM}

If I were a dualist, this is the objection that would worry me most. It doesn't appear to worry those who actually are dualists, though, and it's hard to find an explicit response to it. But some dualists say something that suggests a response, namely

\footnotetext{
${ }^{3}$ Peter van Inwagen, Metaphysics, 4th ed (Boulder, CO: Westview Press, 2014), 260.

${ }^{4}$ René Descartes, The Philosophical Writings of Descartes, ed. and trans. John Cottingham, Robert Stoothoff, and Dugald Murdoch (Cambridge: CUP, 1985), 2:56.
} 
that our mental activity depends on physical activity in the body. The brain does not merely convey messages between the soul and the body, but is necessary for mental life. Swinburne, for instance, says that "the functioning of the soul depends on the correct functioning of the brain." "The soul and the body may be like a human being and a drone she operates by remote control, but they're also like a light bulb and its power source. ${ }^{6}$ If the supply of power is disrupted, the bulb immediately goes dark. That would explain why general anaesthesia stops all mental activity.

Call this view electric dualism. Its main principle is that all mental activity in the soul is caused by physical activity in the body. It may be that mental activity is caused entirely by what happens in the body, or only partly. That is, the right sort of activity in the body might be causally sufficient for the soul to think; or it might be causally necessary but not sufficient, so that thinking also requires nonmental activity in the soul that is not caused by the body. Swinburne's view is presumably that mental activity is caused entirely by physical activity. If it required nonmental activity in the soul as well, the soul would need to have a nonmental as well as a mental nature, which he denies (a point I'll return to in the next section).

Something like this seems the dualist's best reply to the "remote-control" objection. The correlations between our mental activities and the condition of our brains make it hard to maintain that the soul can think without the brain's help.

\section{LIFE AFTER DEATH}

Electric dualism has important implications to do with life after death. Most dualists (including Swinburne) say that the soul can continue existing after the body is destroyed. And they say that the survival of your soul is sufficient for you to survive. Many people accept dualism precisely because it would make life after death possible. And many dualists (again including Swinburne ${ }^{7}$ ) say that disembodied souls can have a mental life: they needn't become re-embodied in order to be conscious. But how can this be if our mental lives depend on the functioning of the brain? If even fairly minor head injuries knock you out cold, how could your mental life continue when your brain is completely destroyed? That's like expecting a light bulb that has gone out because its battery is depleted to light up again when the battery is incinerated.

\footnotetext{
${ }^{5}$ Swinburne, The Evolution of the Soul, 176; see also Swinburne, Are We Bodies or Souls?, 9

${ }^{6}$ Swinburne, The Evolution of the Soul, 310.

${ }^{7}$ Ibid., 311; Swinburne, Are We Bodies or Souls?, 80.
} 
In fact it's hard to see how the soul could even exist without an intact brain. If a soul's mental life depends on physical activity in the brain, its mentality will require the brain to be in a certain condition. So the complete destruction of the brain would deprive the soul of all mental properties. Yet many dualists (including Swinburne ${ }^{8}$ ) believe that the soul's nature is entirely mental. Its only intrinsic properties, apart from certain abstract, "high-category" properties such as being identical to itself or being immaterial, are mental properties: those that entail thought or consciousness. The soul is psychological through and through. And essentially so: it could not possibly have any nonmental properties. Descartes put this by saying, "absolutely nothing else belongs to my nature or essence"- that is, my soul's essence- - "except that I am a thinking thing."

But if the soul cannot have mental properties without an intact brain, and its entire nature must be mental, then destroying the brain would deprive the soul of any intrinsic properties at all - apart, again, from abstract, high-category properties. Yet nothing, or at least no concrete object, could have only intrinsic properties like being self-identical and being immaterial. Destroying the brain would then destroy the soul as well. The soul depends on the brain not just for its mental functioning, but for its very existence, ${ }^{10}$ threatening to make life after death impossible.

Swinburne answers that the dependence of mental life on the brain is merely causal: it's a contingent law of nature. ${ }^{11}$ Our souls could function without any brain at all if the laws were different, or if they were somehow suspended. If there is an afterlife, that's presumably what happens when we die: the psycho-physical laws connecting mental with neural properties no longer apply to us. ${ }^{12}$ Alternatively, a god could miraculously supply the soul with whatever the brain normally provides, just as he could keep a light bulb going after its physical power source is destroyed by miraculously supplying it with electricity. ${ }^{13}$

This would mean that we are not naturally immortal. If nature were to take its course, we should cease to exist at death — or more precisely when our brains are so badly damaged that we lose all mental powers. Life after death requires a suspension of the natural order. ${ }^{14}$ In Plato's dualism, by contrast, the soul depends on the

${ }^{8}$ Ibid., 31.

${ }^{9}$ Descartes, The Philosophical Writings, 2:78.

${ }^{10}$ William Hasker, "Souls Beastly and Human," in The Soul Hypothesis, ed. Mark C. Baker and Stewart Goetz (New York: Continuum, 2011), 213-16; Swinburne, Are We Bodies or Souls?, 9.

${ }^{11}$ Ibid., 9, 155.

${ }^{12}$ Swinburne, The Evolution of the Soul, 309.

${ }^{13}$ Ibid., 311; HaSker, "Souls Beastly and Human," 216.

${ }^{14}$ Ibid., 216. 
body only for sense perception and physical action. But Plato would be hard pressed to explain why head injuries cause unconsciousness.

\section{THE BODY'S MYSTERIOUS INABILITY TO THINK}

Whatever its merits, however, electric dualism faces a problem. Suppose physical activity in the body causes the soul to think. Why is it that the soul thinks and not the body? If neural activity in the body causes thinking, why does it cause it in some other thing and not in itself? How could the body act in a way that suffices to cause thinking without itself being able to think? Or if thinking is caused partly by nonmental activity in the body and partly by nonmental activity in the soul, why is it the soul that thinks with the help of the body, and not the body that thinks with the help of the soul?

No one would suppose that the body thinks in addition to the soul. That would be inconsistent with dualism as I've stated it, which says that nothing is both a thinking thing and a material thing. And it would have absolutely no attraction. If our bodies can think, why suppose that we have souls as well? That would give us two thinkers for each human being, one material and one immaterial. Each would have its own separate mental life. Given that both mental lives would be caused by the same physical activity, they may be exactly alike. The two thinkers may never have conflicting intentions - one wanting to stay at your desk and the other wanting to go out for a walk, say - and struggle for control of your limbs. They may always think the same. But there would be no reason to expect the body's mental life to be introspectively accessible to the soul, or the soul's to the body.

And consider the theological implications. Half of human thinkers - the soulswould be able to exist in a conscious state after death, and half - the bodies-would not. Yet, having identical mental lives, they would appear to have the same moral status and to be equally deserving of everlasting life.

The epistemic consequences would be no less troubling. Suppose my soul were a dualist, and believed that it was immaterial. Then my body, whose mental life would have the same cause, would also be a dualist and believe that it was immaterial. Yet only one of them would be right. Even if dualism were true, half of its adherents would be mistaken: for every immaterial dualist there would be another who was entire material, despite having the same reasons for her belief. Any dualist ought to worry that she herself was one of the material ones. Statistically there would be an even chance of it, and everything would appear exactly the same either way. So even if I were immaterial, I could never know it. But no one who thinks that my body has a soul attached would consider it a further question whether it's 
my soul — the thinker of my thoughts — or take it to be compatible with my being my body.

That the soul and the body both think is a grotesque mockery of the dualist picture. All dualists are confident that our bodies don't think. But it's not clear what grounds this confidence.

So dualists need more than just a reason to suppose that we have thinking souls: they also need a reason to suppose that we don't have thinking bodies. There are plenty of arguments for our having thinking souls. Swinburne, for example, argues that it's necessary to account for our persistence through time. ${ }^{15}$ But this says nothing against the claim that our bodies also think. And the observed fact that thinking requires an intact body suggests that our bodies are causally necessary for thinking, if not sufficient. That suggests that our bodies $d o$ think, even if only with the help of a soul.

Nothing about the nature of physical organisms rules out their having mental properties, or at least not in any obvious way. If they can produce thought yet can't themselves think, there must be a reason why. What could it be?

\section{CONTINGENT LAWS AND THE A PRIORI}

It might be a contingent law of nature. But it's hard to see how we could know that this was a law. We can't know the laws a priori, but only by observation. (The a priori evidence would be the same in all possible worlds, both those were the laws in question hold and those where they don't.) And although the observed behaviour of sticks and stones suggests that they don't think, we can hardly say the same about physical organisms.

What sort of observation would tell us that thinking beings are not the material things we see, but rather immaterial things that we don't see? Well, we could observe physically identical things behaving in very different ways: organisms in a vegetative state that never act in a purposive way no matter what we do to them, say, yet are physically indistinguishable from healthy organisms. That may suggest that they can't think because they're missing a soul. But of course it's not what we do observe.

So if our bodies' thinking were ruled out by a contingent law, we could hardly know it on the basis of observation or experiment: no contingent facts that we can observe provide any evidence for it. If we could nevertheless know that our bodies cannot think, it would have to be a necessary truth. We all know Leibniz's argu-

\footnotetext{
${ }^{15}$ Swinburne, "Personal Identity," 22-31; Swinburne, The Evolution of the Soul, 146-55, chap. 3-5.
} 
ment for this claim: no matter how well we understand the physical workings of any material thing, it's inconceivable that they could produce anything mental; so the mental must reside in a thing without physical workings. ${ }^{16}$ But this reasoning is of no use to electric dualists. If it's inconceivable that brain activity could produce thinking, it makes no difference whether the thinking is done by the body or by the soul. We can no more conceive how brain activity could cause mentality in the soul than in the body.

\section{COOPERATIVE DUALISM}

The claim that we have thinking souls does nothing to rule out our bodies' thinking as well, and the dependence of our thinking on the body looks like a strong reason to suppose that our bodies do think. Until we have an account of why they don't, dualists are in a tight spot.

Here is a proposal that would avoid the problem. Suppose the soul doesn't think. Body and soul each do something necessary for thinking, but neither contribution is sufficient. Each produces something nonmental, and these ingredients combine to make mental activity. What thinks is neither the soul nor the body, but the thing composed of the two. ${ }^{17} \mathrm{~A}$ body and a soul produce thought together much as a tenor and a soprano might sing a duet. No one performs the entire duet: that would be impossible, as it requires two voices sounding at once. The duet has two components, and each singer performs just one of them. Thinking (in human beings, anyway) is likewise an activity having two components, one physical and one nonphysical, each produced by a different entity.

This "cooperative dualism" would make it impossible for a physical organism to think, as thinking would require a nonphysical contribution from the soul. Nor could the soul think, because thinking requires a physical contribution from the body. If the soul were to think with the body's help but the body were unable to think even with the soul's help, there would again be no explanation of this difference, which is the problem we were trying to solve. The thinker must be the thing engaged in both activities: the compound of soul and body. (As I noted earlier, Swinburne himself believes that we are such compounds. But he is no cooperative dualist: he says that the compound thinks only in the derivative sense of having a thinking soul as a part,

\footnotetext{
${ }^{16}$ The best discussion of this topic that I know of is in van Inwagen, Metaphysics, 233-40.

${ }^{17}$ If this conflicts with the traditional definition of "soul" as an immaterial thinker, we could instead define it as an immaterial thing whose activity enables something to think.
} 
whereas cooperative dualism says that the compound thinks in the strictest sense and denies that the soul thinks at all.)

Now this still leaves us wondering why the body's physical activity is insufficient to cause mental activity. Why should thinking require a nonphysical contribution from the soul as well? Cooperative dualism does not answer this question. But this is a less troubling mystery than the one attending electric dualism. The really baffling claim is that the body acts in a way that is sufficient to cause thinking, yet still cannot think (or, alternatively, that the activity of both body and soul is necessary for thinking, but only the soul can think). Cooperative dualism avoids this. It makes no claims that, so to speak, arbitrarily favour the soul over the body. Electric dualism says that the body's physical activity causes the soul to think but not the body, without providing any explanation for this asymmetry. Cooperative dualism treats the body and the soul equally, saying that neither can think because, for whatever reason, neither can produce mental activity on its own. Though that leaves unanswered questions, it's more principled than electric dualism. (I'll return to these points in section 9.)

Cooperative dualism would explain what happens in general anaesthesia as well as electric dualism does. If mental activity had both a physical component in the brain and a nonphysical one in the soul, changes in the brain could make it impossible by stopping the physical component, even if the soul continues to function. If you and I are singing a duet and I suddenly lose my voice, the duet will stop, even if you continue to sing. Likewise, if your brain and your soul are cooperating to produce thinking and your brain stops working, your mental activity will stop, even if your soul, so to speak, keeps on singing.

What about life after death? Cooperative dualists might say, as Swinburne does, that it's due only to a contingent causal law that our thinking requires physical activity. If disembodied souls were somehow exempt from this law, they might then think unaided. But this would introduce an arbitrary and mysterious element very like the one we were trying to avoid, namely that it's metaphysically possible for souls to think but not for bodies: no dualist would say that destroying our souls would enable our bodies to think by exempting them from the law saying that thinking requires a nonphysical contribution from the soul. For cooperative dualism to have any point, it needs to rule out the possibility that either souls or bodies could think.

\section{THE UNKNOWN NATURE OF THE SOUL}

No one, to my knowledge, has ever advocated cooperative dualism. One reason for this may be that it's not actually a version of substance dualism as it's usually stated. Dualism says that concrete objects come in two exclusive kinds: thinking 
things and material things. Cooperative dualism agrees that concrete objects come in two kinds and that one of them is material and unthinking. The two views say more or less the same about material things. But cooperative dualism says something radically different about immaterial things: they don't think. It denies not only that the soul's entire nature is mental, but that it has any mental properties at all.

What properties has a soul got, then? It must have some properties - some intrinsic nature apart from merely being self-identical, immaterial, and the like. It has to $d o$ something - to engage in some activity that combines with what happens in the brain to produce thinking. Call this nature or activity $X$. Cooperative dualism is a sort of dualism, in that it divides the world into two exclusive and metaphysically independent realms. But these realms are not the physical and the mental, but rather the physical and X.

This is not just troubling for those who like philosophical theories to fall into neat categories. It downgrades the status of the mental. Traditional dualism says that the physical and the mental are fundamental: they don't consist in anything else. Material things don't have their physical properties by virtue of their having certain nonphysical properties. Nor does the psychological nature of thinking things consist in anything nonmental (even if, as a matter of contingent fact, it has a nonmental cause). The two realms are metaphysically on a par. But cooperative dualism implies that although the physical may be fundamental, the mental is not. Our mental activity consists in something nonmental, namely the body's physical activity together with $\mathrm{X}$. The mental is metaphysically second rate.

And it makes the soul opaque. Traditional dualism makes the soul comfortingly familiar: its nature consists of conscious awareness, memory, belief, emotion, and so on. Cooperative dualism makes the soul completely unknowable. No one knows what X might be, or how to find out. The properties of souls that are analogous to physical properties like mass, velocity, and temperature are unobservable. The physical sciences tell us about the nature of material things, but there is no science of X. And psychology can only tell us about the mental nature of soul-body compounds. All we can know about the soul, it seems, is that whatever it does somehow combines with the body's activity to produce thinking.

Dualists normally suppose that one's own soul is the entity one knows best. (This is the thought behind Swinburne's claim that the word ' $\mathrm{I}$ ' is an "informative designator": that simply knowing its meaning reveals the essential nature of its referent. ${ }^{18}$ ) This knowledge may be incomplete: the soul may have unknown depths.

${ }^{18}$ Richard Swinburne, "The Argument to the Soul from Partial Brain Transplants," Philosophia Christi 20 (2018): 13-19; Swinburne, Are We Bodies or Souls?, 86-108; see also Olson, "Swinburne's Brain Transplants." 
But we know what sort of thing inhabits those depths: memories, desires, fears, and so on. Cooperative dualism implies that we cannot know even what lies on the surface. We may not be surprised if the Oracle told us that the world contained something utterly unknowable. But no one would expect that thing to be the soul.

\section{THE ASYMMETRICAL DIALECTIC \\ BETWEEN DUALISM AND MATERIALISM}

Cooperative dualism may be fascinating, but it has little appeal. Yet any version of dualism requires there to be an account of why it's metaphysically impossible for a material thing to have mental properties. (I argued in section 6 that no dualist would take our bodies' inability to think to be merely contingent.) There must be a reason why thinking and being made of matter are like being round and being square, not like being round and being red. And if the soul needs to be attached to a working brain in order to think, as electric dualism says, this account must be compatible with the claim that material things can produce thinking.

Arguments for dualism do not provide such an account. Showing that we (who think) are immaterial does nothing to explain why our bodies don't think, never mind why this is impossible. Or at least this is so unless we argue, as Leibniz did, that we must be immaterial precisely because no material thing could think. But as we have seen, any reason to suppose that no material thing could think looks like a reason to suppose that no material thing could produce thinking either. Yet the observed facts about general anaesthesia and head injuries seem to show that material things do produce thinking. Relying on Leibniz's argument would leave us without a solution to the remote-control problem.

So even if we could show conclusively that we must be immaterial, our work would not be finished. We'd still want to know why material things can never think.

You might reply that materialism - the view that we're material things - is no better off. It's not enough for materialists to argue for their view: they must also explain how it's possible for a material thing to think. I've argued that the dualist project consists not just of showing that we're immaterial, but of answering an explanatory question:

Question 1 (for dualists): Why is it impossible for a material thing to think?

But the materialist project likewise consists not just of showing that we are material, but in answering another explanatory question:

Question 2 (for materialists): How is it possible for a material thing to think? 
If dualists have no good answer to their question, the thought goes, that's no grounds for complaint, as materialists haven't answered theirs either: there is no satisfying account of how a material thing can think.

This presupposes that every "theory of mind" that has been proposed over the past seventy years has been a complete failure. But even if that's true, the reply misrepresents the dialectical situation.

For one thing, the claim that material things can think is hardly surprising - especially given the apparent fact that they can produce thinking. And many material things act as if they were conscious and intelligent. Materialism may raise an unanswered question, but it's hardly a great mystery. The materialists' failure to answer their question is considerably less troubling than the dualists' failure to answer theirs.

What's more, the two questions are disanalogous. The dualistic analogue of the materialist's question is not explaining why a material thing could not think but explaining how an immaterial thing could think. If materialism demands an answer to question 2, dualism demands an answer to a third question:

Question 3 (for dualists): How is it possible for an immaterial thing to think?

(Cooperative dualists instead face the question of why it's impossible for souls to think.) No answer to this question has ever been given. This fact may be obscured by the dualists' claim that it belongs to the essential nature of an immaterial thing to think. But you can't explain how it's possible for a thing to think by saying that thinking belongs to its nature: that just presupposes the fact that needs explaining. Materialists could just as easily say that it belongs to the nature of certain material things to think. No one would mistake that for an explanation. It's no easier to say how an immaterial thing could think than to say how a material thing could think. ${ }^{19}$ Or if question 3 is somehow illegitimate and there need not or could not be an account of how an immaterial thing could think, then question 2 will be illegitimate for the same reason.

And given the apparent causal dependence of the mental on the physical, dualism raises the further question of how it's possible for a material thing to produce thinking:

Question 4: How is it possible for a material thing to produce mental activity?

Of course, materialism raises this question too. But materialists will see no difference between producing mental activity and being engaged in it - that is, between causing thinking and thinking. By their lights, question 4 is the same as question 2

\footnotetext{
${ }^{19}$ See the very forceful discussion of this point in van Inwagen, Metaphysics, 235-40.
} 
or at least it will have the same answer. Knowing how a material thing could produce thinking will tell us how it could think.

Both dualism and materialism raise hard questions, and neither will be satisfying until these questions are answered. Both projects require an account of how a material thing can produce thinking (question 4), which materialists will take to explain how a material thing can think. (Platonic dualists don't face this question, but they'll have a hard time answering the remote-control objection.) And dualists have two further explanatory tasks that have no analogue in the materialist project: why no material thing could think (question 1) and how it's possible for an immaterial thing to think (question 3). Even if the arguments for dualism are just as forceful as those for materialism, the dialectic favours materialism. ${ }^{20}$

\section{BIBLIOGRAPHY}

Descartes, René. The Philosophical Writings of Descartes. Vol. 2. Edited and translated by John Cottingham, Robert Stoothoff, and Dugald Murdoch. Cambridge: CUP, 1985.

Hasker, William. "Souls Beastly and Human." In The Soul Hypothesis, edited by Mark C. Baker and Stewart Goetz. New York: Continuum, 2011.

Olson, Eric T. "A Compound of Two Substances." In Soul, Body, and Survival, edited by Kevin Corcoran. Ithaca, NY: Cornell University Press, 2001.

Olson, Eric T. "Swinburne's brain transplants.” Philosophia Christi 20 (2018): 21-29.

Swinburne, Richard. "Personal Identity: The Dualist Theory." In Personal Identity, edited by Sydney

Shoemaker and Richard Swinburne. Oxford: Blackwell, 1984.

SwInburne, Richard. The Evolution of the Soul. Revised edition. Oxford: OUP, 1997.

Swinburne, Richard. "The Argument to the Soul from Partial Brain Transplants." Philosophia Christi 20 (2018): 13-19.

Swinburne, Richard. Are We Bodies or Souls? Oxford: OUP, 2019.

Van Inwagen, Peter. Metaphysics. 4th ed. Boulder, CO: Westview Press, 2014.

\section{THE DUALIST PROJECT AND THE REMOTE-CONTROL OBJECTION}

\section{Sum mary}

Substance dualism says that all thinking beings are immaterial. This sits awkwardly with the fact that thinking requires an intact brain. Many dualists say that bodily activity is causally necessary for thinking. But if a material thing can cause thinking, why can't it think? No argument for dualism, however convincing, answers this question, leaving dualists with more to explain than their opponents.

Keywords: Swinburne; personal identity; immortality.

\footnotetext{
${ }^{20}$ For comments on earlier versions I am grateful to Karsten Witt and Dean Zimmerman.
} 